\title{
APP-045 EXPRESSION OF A NOVEL BIOMARKER, EPCA, IN ADENOCARCINOMAS AND PRECAN- CEROUS LESIONS IN THE PROSTATE.
}

\begin{abstract}
坂出市立病院泌尿器科11, 神鋼病院泌尿器科2), 香川大学医学部泌尿器科 ${ }^{3)}$, 香川大学医学部病理部

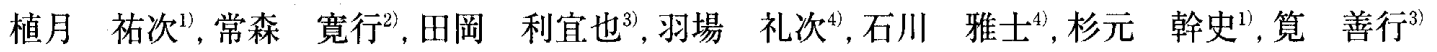

<目的>EPCA は nuclear matrix protein であり, Dunning ラットの prostate cancer model から分離された Am-1 の counterpart である EPCA はヒトの前立腺癌組織に特異的に反応し, 前立腺肥大症では発現しないことが報告さ れている，今回我々は外科的に切除された前立腺癌組織を用い，EPCAの発現と局在について解析した，<材料と方 法 $>2001$ 年 7 月から 2003 年 8 月までの期間に香川医科大学付属病院において限局性前立腺癌の診断で前立腺全摘 術を受けた患者 50 名とコントロールとして浸潤性膀胱癌の診断で膀胱前立腺全摘術を受けた患者 10 名の前立腺組 織を採取した. すべての患者には香川大学医学部の治験ガイドラインに基づき書面で同意を得た. 前立腺組織はパラ フィン包埋後薄切し, HE 染色, EPCAによる免疫染色を行った. 病理医により TNM 分類, グリソンスコアを診断 され，最も腫瘍の大きい部分の primary Gleason score と染色強度について検討した．特に腫湯に隣接する切片も注 意深く観察し, high grade prostatic intraepithelial hyperplasia（以下 PIN）や proliferative inflammatory atrophy (以下 PIA) があるか診断した. PIN,PIA は前立腺癌の前癌病変であるという報告があり，それらの組織についても EPCA の免疫染色を行った. PIN の診断は HE 染色の病理的診断だけでなく, P504S と p63 と高分子量のサイトケラ チンのカクテルの抗体を用い診断した. PIA も HE 染色による腺の萎縮と炎症細胞浸潤の診断だけでなく, 炎症細胞 浸潤の証拠として CD45RO (Tcell マーカー)による免疫染色を行った. （結果>EPCA は 50 例の前立腺癌標本のう ち 47 例（94\%）で陽性であったが，膀胱癌患者から得られた正常前立腺では 10 例全例陰性であった（ $<0.0001$, Fisher's exact test). 染色強度と病理学的 T 分類, 主病巣の Gleason score, 術前の PSA 值と相関は認めなかった. 前立腺癌標本の 50 例中 43 例 $(83 \%)$ に前癌病変であると考えられる high grade PIN と PIA が認められ EPCA 染色 は陽性であった。結論>EPCA は前立腺癌の前癌病変における nuclear matrix protein の早期の变化を反映してお りこの変化は EPCA が前立腺㾔の新規腫痬マーカーとしての可能性を示唆するものであると考えられる.
\end{abstract}

\section{APP-046 Angiotensin II 1 型受容体阻害剂によるホルモン抵抗性前立腺癌の克服}

\section{慶應義塾大学医学部泌尿器科学}

宮嶋 哲, 菊地 栄次, 中川 健, 大家 基嗣, 大東 貴志, 中島 淳, 村井 勝

【目的】 Angiotensin II 1 型受容体 (AT1R) 阻害剂は降圧剂として普及しているが，近年，その血管新生抑制を介した抗腄漡効 果が注目されている，我々はこれまで，ヒトならびにマウス腎癌肺転移巣でAT1Rの発現を認め，AT1R 阻害郕の投与により 血管新生抑制を介し，腎癌肺転移巣を劇的に抑制することを証明してきた，本研究ではヒトおよびマウス前立腺癌における血 管新生とAT1Rの発現を検討し，マウス皮下腫瘍モデルでホルモン感受性とATIR 阻害剤の効果について比較検討した.

【方法】ホルモン抵抗性前立腺癌（HRPC）の剖検標本と抗アンドロゲン療法を施行されていない限局性前立腺癌の前立腺摘出 標本 $(\mathrm{PC})$ を用いて，前立腺澺に㧍けるVEGF, AT1R, CD34の発現について免疫組織学的に検討を行った. 次にホルモン感受

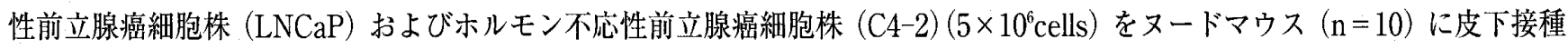
後，AT1R 阻害剂（カンデサルタン， $10 \mathrm{mg} / \mathrm{kg} / \mathrm{day}$ ）を経口投与した．4週後に腫場容積，腫場内での微小血管密度（MVD） ならびに VEGF の発現についてコントロール群と比較検討した。

【結果】HRPC 標本では, PC 標本 $(0.8 \pm 0.4 ; 35.3 \pm 2.7, \mathrm{n}=25)$ に比して有意に高いVEGF の発現 $(1.9 \pm 0.6, \mathrm{p}<0.01)$ および MVD $(65.1 \pm 6.3, \mathrm{n}=24, \mathrm{p}<0.01)$ を認めた．さらに HRPC 標本では，PC 標本に比して AT1Rの発現率が高かった．ママウス皮下腫瘍

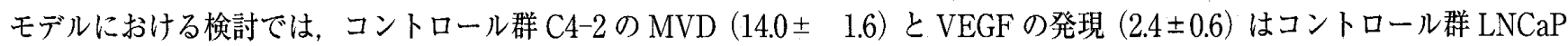
に比して有意に高かった $(7.7 \pm 1.2 ; 1.1 \pm 0.2, \mathrm{p}<0.01)$. カンデサルタン投与群 C4-2 での MVD と VEGF 発現はコントロール群 C4-2 に比して有意に低かった $(5.9 \pm 0.8 ; 1.6 \pm 0.4)$. 皮下腫瘍誘導後 4 週後に抢けるカンデサルタン投与群 C4-2 の腫噶容積 $\left(215 \pm 32 \mathrm{~mm}^{3}\right)$ ならびに血清 PSA 濃度 $(45.0 \pm 17.6 \mathrm{ng} / \mathrm{ml}, \mathrm{n}=5, \mathrm{p}<0.01)$ は，コントロール群 $\mathrm{C} 4-2\left(845 \pm 163 \mathrm{~mm}^{3} ; 376.7 \pm\right.$ $24.2 \mathrm{ng} / \mathrm{ml})$ に比して有意に抑制されていた.

【結論】ホルモン不応性前立腺癌では，ホルモン感受性前立腺癌に比してょり多くの血管新生が誘導されており，AT1R 阻害剤 による血管新生抑制を介する抗腫瘍効果が有効であり，AT1R 阻害剤の投与によってホルモン不応性を克服できる可能性が示 唆された。 